\title{
Impact of Indoxyl Sulfate on Progenitor Cell-Related Neovascularization of Peripheral Arterial Disease and Post-Angioplasty Thrombosis of Dialysis Vascular Access
}

\author{
Chih-Cheng Wu ${ }^{1,2,3}$, Szu-Chun Hung ${ }^{4}$, Ko-Lin Kuo ${ }^{4}$ and Der-Cherng Tarng ${ }^{5,6, *}$ \\ 1 Cardiovascular Center, National Taiwan University Hospital, Hsinchu Branch, Hsinchu 30059, Taiwan; \\ chihchengwumd@gmail.com \\ 2 National Tsing-Hua University, Institute of Biomedical Engineering, Hsinchu 30013, Taiwan \\ 3 School of Medicine, National Yang-Ming University, Taipei 11217, Taiwan \\ 4 Division of Nephrology, Taipei Tzu Chi Hospital, Buddhist Tzu Chi Medical Foundation and \\ School of Medicine, Tzu Chi University, Hualien 97004, Taiwan; szuchun.hung@gmail.com (S.-C.H.); \\ kolinkuo8@gmail.com (K.-L.K.) \\ 5 Institutes of Physiology and Clinical Medicine, National Yang-Ming University, Taipei 11217, Taiwan \\ 6 Division of Nephrology, Department of Medicine, Taipei Veterans General Hospital, Taipei 11217, Taiwan \\ * Correspondence: dctarng@vghtpe.gov.tw; Tel.: +886-2-2875-7517; Fax: +886-2-2875-7841
}

Academic Editor: Raymond Vanholder

Received: 4 November 2016; Accepted: 4 January 2017; Published: 7 January 2017

\begin{abstract}
Patients with chronic kidney disease (CKD) have an increased risk of vascular disease, which is associated with considerable health care costs. Vascular disease in CKD differs clinically and pathobiologically from that in patients with normal renal function. Besides the traditional risk factors, retention of uremic toxins contributes to the pathogenesis of vascular disease in patients with CKD. Indoxyl sulfate is a protein-bound uremic toxin and is inefficiently removed by conventional dialysis. Accumulating evidence suggests that indoxyl sulfate is a vascular toxin involved in atherosclerosis, arteriosclerosis, vascular calcification and vascular repair. Clinically, indoxyl sulfate is associated with total and cardiovascular mortality in patients with CKD. Recent studies have indicated that in addition to coronary and cerebral arteries, indoxyl sulfate plays a role in peripheral artery disease (PAD) and dialysis graft thrombosis. Emerging evidence suggests that indoxyl sulfate is implicated via novel mechanisms, including progenitor cell-related neovascularization and tissue factor-related hypercoagulability. These findings raise the possibility that strategies targeting serum indoxyl sulfate may have the potential to improve the outcomes of PAD and dialysis vascular access in patients with CKD.
\end{abstract}

Keywords: chronic kidney disease; dialysis vascular access; indoxyl sulfate; peripheral artery disease; thrombosis; uremic toxin

\section{Chronic Kidney Disease and Vascular Disease}

\subsection{Chronic Kidney Disease and Vascular Disease}

Compared to patients with preserved kidney function, patients with chronic kidney disease (CKD) are more likely to develop atherosclerotic vascular disease. Vascular disease-related ischemic events cause significant morbidity and mortality in patients with CKD [1]. An increased risk of myocardial infarction and ischemic stroke has been widely reported in patients with CKD [1-6]. In addition to cerebral and coronary artery disease, peripheral artery disease (PAD) is highly prevalent among patients with CKD [7]. Creation of vascular accesses for dialysis, including native arteriovenous 
fistulas (AVFs) and prosthetic arteriovenous grafts (AVGs), is also frequently associated with stenosis and thrombosis $[8,9]$. Although traditional vascular risk factors are common in patients with CKD, they cannot sufficiently account for the increased vascular events [2]. Understanding the unique pathophysiology of vascular disease in patients with CKD may help to develop strategies for prevention and therapy. In the following sections, we will focus on the novel mechanisms of the effect of indoxyl sulfate on PAD and dialysis vascular accesses.

\subsection{Peripheral Arterial Disease in Patients with Chronic Kidney Disease}

In both the general population and patients with CKD, the risk of PAD increases as the values of glomerular filtration rate (GFR) decline, even after adjustment for possible confounders. The prevalence of PAD increases in patients with CKD, ranging from 7\% in Stage 3 to $45 \%$ in Stage 5D, which is ten-fold higher than that observed in the general population [7]. Moreover, PAD in patients with CKD presents a unique challenge owing to the poor outcome of revascularization [10]. As a result, the limb amputation rate remains high, and the mortality and morbidity associated with PAD is much higher than that of patients with preserved renal function [6].

\subsection{Vascular Access Dysfunction in Patients on Hemodialysis}

Dysfunction of dialysis vascular accesses continues to be a major source of morbidity and mortality in patients with end-stage renal disease (ESRD). After publication of the dialysis outcome quality initiative guidelines, endovascular interventions have replaced surgical revisions as the primary therapy for dialysis access dysfunction [11]. Although percutaneous transluminal angioplasty (PTA) can achieve a high success rate, recurrent stenosis and thrombosis are usually inevitable. At one year after PTA, only $26 \%-58 \%$ of native fistulas remain functional without subsequent interventions [12]. The outcome of graft accesses is worse than that of native fistulas, as only $40 \%-50 \%$ of AVGs remain functional at six months after intervention. If thrombosis develops in AVGs, the three-month unassisted patency rate ranges from $30 \%$ to $40 \%$ [13]. As a result, repeated interventions are usually required, placing a substantial financial burden on the health care system [8].

\section{Vascular Toxicity of Indoxyl Sulfate}

Indoxyl sulfate is one of the protein-bound uremic toxins produced by intestinal bacteria as a degradation product of the amino acid tryptophan. Indoxyl sulfate accumulates in CKD, mostly bound to albumin, and is therefore not sufficiently removed by means of conventional dialysis. Increasing number of studies suggest that, in addition to the involvement in the progression of CKD, indoxyl sulfate contributes to the progression of vascular dysfunction.

In clinical studies, indoxyl sulfate is a powerful predictor of overall and cardiovascular mortality in patients with CKD [14,15]. Indoxyl sulfate is positively correlated with aortic calcification and pulse wave velocity [14]. In patients on hemodialysis, indoxyl sulfate is associated with markers related to atherosclerosis, endothelial function, and the incidence of PAD [16-18].

Indoxyl sulfate causes endothelial dysfunction in many ways. It increases endothelial oxidative stress via an increase in NADPH oxidase activity and a decrease in intracellular glutathione levels [19]. It causes activation of leukocytes, proliferation of smooth muscle cells, and decrease in nitric oxide availability [20]. These mechanisms are associated with endothelial dysfunction and atherosclerosis progression. Indoxyl sulfate promotes aortic calcification and aortic wall thickening in hypertensive rats, which is manifested by aortic wall thickening and expression of osteoblast-specific proteins [21,22]. Therefore, indoxyl sulfate may be responsible for vascular calcification and arterial stiffness in patients with CKD. Indoxyl sulfate inhibits endothelial proliferation and wound repair, but stimulates the proliferation of vascular smooth muscle cells [23-25]. Both the proliferative and antiproliferative effects of indoxyl sulfate lead to abnormal vascular repair and neointima hyperplasia (Table 1).

In addition to the above pathways, pro-thrombosis and angiogenesis have been discovered in recent studies as novel mechanisms by which indoxyl sulfate causes vascular dysfunction. In this 
review, we focus on the effect of indoxyl sulfate on the angiogenesis of PAD and thrombosis of dialysis vascular accesses.

Table 1. Primary effect of indoxyl sulfate on the different types of cells involved in vascular dysfunction of chronic kidney disease.

\begin{tabular}{ccc}
\hline Cells & Primary Effect & Reference \\
\hline \multirow{4}{*}{ Endothelial cell } & Induction of ROS & Dou [26], Yu [17], Itoh [27] \\
& Inhibit endothelial NO production & Yu [17] \\
& Increase endothelial microparticle release & Faure [28] \\
& Increase tissue factor production & Gondouin [29] \\
& Inhibit endothelial cell proliferation & Dou, Yu [17] \\
& Inhibit endothelial cell migration & Kharait [30] \\
\hline \multirow{2}{*}{ Smooth muscle cell } & Increase proliferation & Yamamoto [24] \\
& Inhibit proliferation & Mozar [31] \\
& Reduce tissue factor breakdown & Chitalia [32] \\
\hline \multirow{2}{*}{ Leukocyte } & Increase leukocyte adhesion & Ito [33], Tumur [20], Pletinck [34] \\
& Increase inflammatory cytokine expression & Lekawanvijit [35] \\
\hline Progenitor cell & Induction of ROS & Wu [36] \\
& Inhibit NO production & Wu [36] \\
& Inhibit HIF/IL-10/VEGF pathway & Hung [37] \\
& Decrease in number and function & Hung [37], Wu [36] \\
\hline
\end{tabular}

HIF, hypoxia-inducible factor; NO, nitric oxide; ROS, reactive oxygen species; VEGF, vascular endothelial growth factor.

\section{Indoxyl Sulfate and Progenitor Cell-Related Neovascularization}

\subsection{Angiogenesis and Peripheral Arterial Disease in Chronic Kidney Disease}

PAD in CKD is associated with an increased risk of mortality and morbidity, including limb amputation, and therapy for this condition is challenging [7]. Progression of atherosclerosis, which is accelerated by uremic state, may be the main cause of poor outcome in patients with CKD. Endothelial dysfunction is an early marker of atherosclerosis. In CKD, oxidative stress and nitric oxide (NO) deficiency play an important role in endothelial dysfunction. Tumur et al. have shown that indoxyl sulfate inhibits endothelial cell viability by inhibition of NO production [38]. Several studies described that indoxyl sulfate upregulates the expression of adhesion molecules and enhances leukocyte-endothelial cell interactions [20,33,34]. These findings suggest that indoxyl sulfate may contribute to the progression of atherosclerosis in patients with CKD by inducing inflammation and endothelial dysfunction.

Neovascularization, defined as the sprouting of new blood vessels from pre-existing vascular structures, is an essential physiological process to cope with tissue ischemia. The ability of collateral vessel formation in ischemic tissues is decreased in patients with CKD [39]. In a rat model, Jacobi et al. showed impairment of neovascularization owing to increased free radical production in CKD [40]. Neovascularization involves the proliferation of both local endothelial cells and circulating endothelial progenitor cells (EPCs) derived from the bone marrow [41]. EPCs have been reported to improve angiogenesis and wound healing [42]. Patients with advanced CKD show a decline in the number and function of EPCs [43]. However, information regarding the effect of indoxyl sulfate on EPC-mediated neovascularization is scarce.

\subsection{Mechanisms Underlying the Effect of Indoxyl Sulfate on Neovascularization}

Indoxyl sulfate has been shown to have direct effects on EPCs through NO-dependent pathways both in vitro and in vivo. In cultured EPCs, indoxyl sulfate decreased the expression of phosphorylated endothelial NO synthase and vascular cell adhesion molecule-1, and increased reactive oxygen species. 
These effects led to decreased homing capacity and proliferative capacity, increased senescence and autophagy, as well as decreased migration and angiogenesis of EPCs [36].

Indoxyl sulfate also suppresses the angiogenic function of EPCs by inhibiting hypoxia-induced HIF-1 $\alpha$ activation and consecutive interleukin (IL)-10 and VEGF synthesis [37]. In vitro, indoxyl sulfate inhibited hypoxia-induced EPC migration and tube formation. These effects could be mitigated by the addition of IL-10 and VEGF. In human EPCs, indoxyl sulfate suppressed the up-regulation of VEGF, IL-10, and HIF-1 $\alpha$. Experiments with HIF-1 $\alpha$ siRNA and an IL-10 inhibitor demonstrated that an increase in HIF- $1 \alpha$ and, consequently, in IL-10 increase is necessary to enhance VEGF levels.

Accumulating evidence shows that the cardiovascular effect of indoxyl sulfate is mediated by activation of the aryl hydrocarbon receptor (AHR) [29,44]. AHR requires aryl hydrocarbon receptor nuclear translocator (ARNT) to regulate gene expression. ARNT, also called HIF- $1 \beta$, is required by HIF- $1 \alpha$ to enhance gene expression in response to hypoxia. Indoxyl sulfate is an endogenous ligand of AHR. Activation of AHR by indoxyl sulfate suppresses the accumulation of the HIF-1 $\alpha$-ARNT complex in the nucleus in inverse proportion to the increase in the nuclear AhR-ARNT complex, resulting in inhibition of HIF- $1 \alpha$ activity [45].

The effect of indoxyl sulfate on neovascularization in ischemic hindlimbs has been demonstrated in an animal model [37]. Subtotal nephrectomy was performed in eight-week-old male C57BL/6 mice, which were then divided into three groups, namely the vehicle group, the indole group, and the indole plus AST-120 group. Eight weeks later, unilateral hindlimb ischemia (HI) surgery was performed on all animals. At Week 2 and Week 4 after HI surgery, the blood flow recovery was significantly impeded in the indole group compared with the vehicle group, but was improved in the indole plus AST-120 group. In parallel, compared with the vehicle group, circulatory Sca1/Flk-1-positive EPCs and the density of $\mathrm{CD} 31^{+}$capillary neovessels in the muscle of ischemic limbs were significantly reduced in the indole group. Similarly, the reductions were significantly reversed in the indole plus AST-120 group. Our results support the concept that indoxyl sulfate may be a therapeutic target for the progenitor cell-related neovascularization of ischemic tissue. The likely mechanisms underlying the effect of indoxyl sulfate on EPCs and neovascularization are summarized in Figure 1.

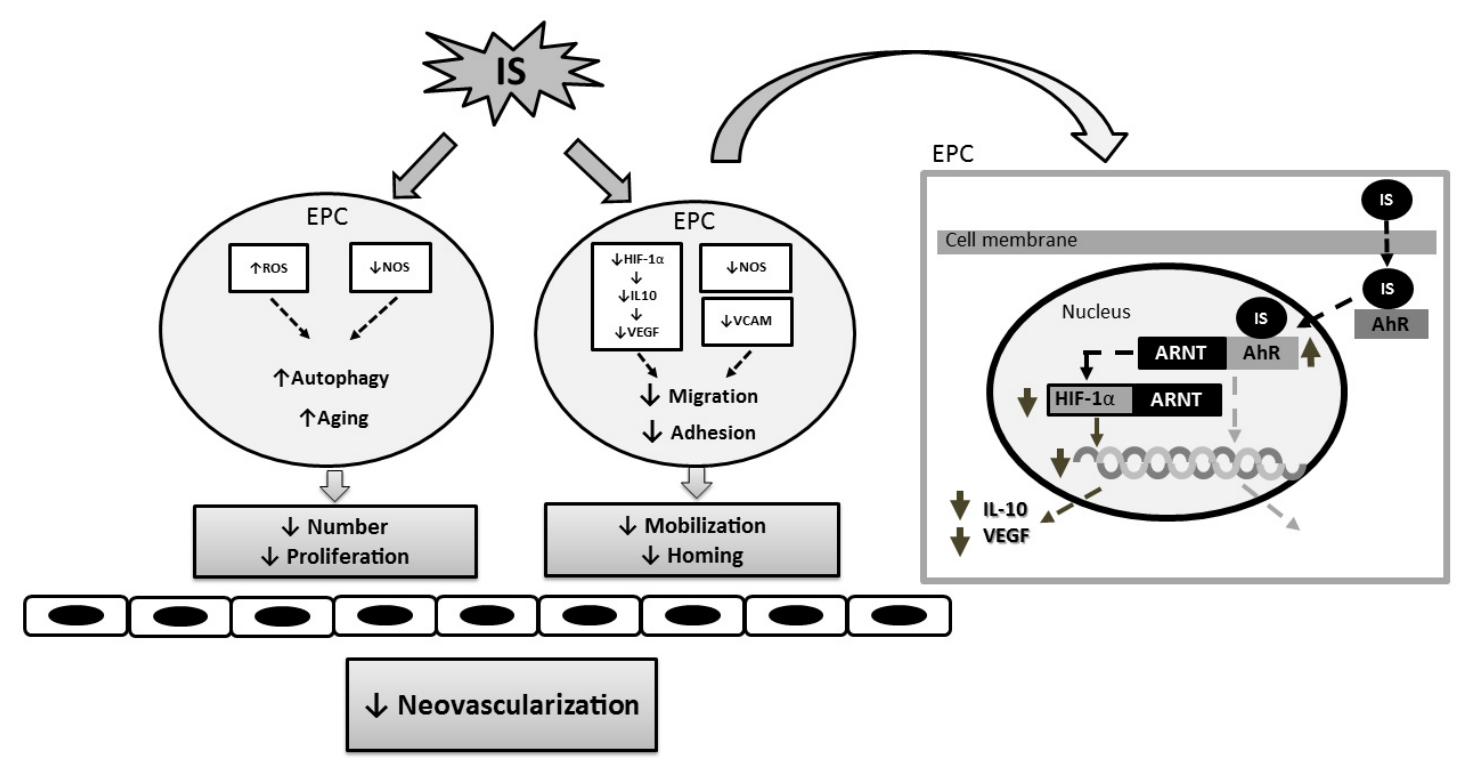

Figure 1. Mechanisms of the effect of indoxyl sulfate on neovascularization in patients with kidney disease (AhR, aryl hydrocarbon receptor; ARNT, aryl hydrocarbon receptor nuclear translocator; EPC, endothelial progenitor cell; IS, indoxyl sulfate, NOS, nitric oxide synthase; ROS, reactive oxygen species; HIF, hypoxic induced factor; IL-10, interleukin-10; VCAM, vascular cell adhesion molecule; VEGF, vascular endothelial growth factor). 


\section{Indoxyl Sulfate and Thrombosis of Dialysis Vascular Accesses}

\subsection{Thrombosis of Dialysis Vascular Accesses}

Thrombosis is the most common cause of secondary vascular access failure [46]. According to Virchow's triad, vascular thrombosis involves an interplay among blood stasis, vessel injury, and hypercoagulability [47]. A major predisposing factor for thrombosis of vascular accesses is stenoses in the outflow veins, which cause blood stasis and are noted in $60 \%-80 \%$ of the cases. Nonetheless, $20 \%-40 \%$ of the cases still occur in the absence of stenosis. In addition, not all vascular accesses with stenoses experience thrombosis; thus, there must be other factors contributing to thrombosis. For example, low-flow state secondary to hypotension has been proposed to precipitate thrombosis [48]. Other causes, such as vascular injury, inflammation, and inadequate hemostasis of dialysis accesses, may also precipitate the development of vascular access thrombosis [49]. Previous studies have demonstrated a prothrombotic state in patients on hemodialysis $[1,2,50-53]$. Both inherited and acquired thrombophilia have been reported as possible causes of dialysis access thrombosis [54-56]. Nonetheless, neither antiplatelet drugs nor anticoagulants have a significant effect.

Recently, indoxyl sulfate was implicated in the increased risk of thrombosis in patients on hemodialysis. In a study on 100 patients on hemodialysis without vascular access dysfunction, baseline indoxyl sulfate levels were linked to the number of vascular access thrombectomies over three years [18]. In another study on 306 patients with vascular access dysfunction, baseline serum indoxyl sulfate levels were associated with thrombosis of vascular accesses after endovascular interventions [57]. A total of 175 patients with graft accesses and 131 patients with native accesses were enrolled. After a median follow-up of 32 months, indoxyl sulfate levels independently predicted thrombotic events of vascular accesses only in patients with graft accesses. No association between indoxyl sulfate and restenosis was found. These clinical studies suggest that indoxyl sulfate may be involved in the thrombotic events of dialysis vascular accesses. Nonetheless, animal models or therapeutic trials are required to validate these observational findings.

\subsection{Mechanisms Underlying the Effect of Indoxyl Sulfate on Thrombosis}

Blood stasis secondary to stenoses is the most common mechanism for thrombosis of dialysis vascular accesses. Nonetheless, the role of indoxyl sulfate in stenoses of dialysis vascular accesses remains unclear. Indoxyl sulfate has been demonstrated to play a critical role in renal fibrosis, mediated by inflammatory reactions and pro-fibrotic cytokines [58]. Nonetheless, both proliferative and antiproliferative effects of indoxyl sulfate on smooth muscle cells have been reported in vitro $[14,59,60]$. In a hypertensive rat model, indoxyl sulfate induced cell cycle inhibitors and caused cell senescence in the calcification area of arcuate aorta [60]. The net effect of indoxyl sulfate on the development of intimal hyperplasia still needs to be determined.

In recent years, a growing body of evidence showed that indoxyl sulfate increases the tissue factor in endothelial cells and vascular smooth muscle cells [32,33]. Tissue factor is a crucial mediator of vascular thrombosis. Using a de-endothelialized, postinterventional model, Chitalia et al. exposed human vascular smooth muscle cells to coronary-like blood flow. These smooth muscle cells were pretreated with uremic serum obtained from patients with ESRD. Uremic serum significantly upregulated the tissue factor in vascular smooth muscle cells [32]. In a subsequent study, they showed that indoxyl sulfate regulated tissue factor stability through the AHR signaling pathway, and that AHR was an effective antithrombotic target [44]. Circulating tissue factor was elevated in patients with CKD and was positively correlated with plasma indoxyl sulfate levels [33]. The indolic uremic solutes increased the production of tissue factors by AHR activation in endothelial cells, evoking a "dioxin-like" effect. These findings suggest that indoxyl sulfate and AHR may comprise a promising therapeutic platform to treat or prevent thrombosis in patients with CKD [34].

An intact endothelium possesses both anti-platelet and anti-thrombotic properties. Exposure of the subendothelial matrix is highly thrombogenic. Therefore, re-endothelialization may be 
another critical factor related to thrombosis after endovascular therapy. Indoxyl sulfate inhibits endothelial proliferation and impairs wound repair in vitro [43]. Endothelial progenitor cells have been shown to mobilize and incorporate into the denuded vessel wall, a process associated with accelerated re-endothelialization [61]. Clinical studies have shown progenitor cell deficiency to be associated with restenosis and thrombosis after endovascular intervention [62-64]. Indoxyl sulfate has a deleterious effect on progenitor cell function, which may precipitate thrombosis through delayed re-endothelialization [36]. Nonetheless, the link among indoxyl sulfate, re-endothelialization and thrombosis still remains unclear. The possible pro-thrombotic mechanisms of indoxyl sulfate are summarized in Figure 2.

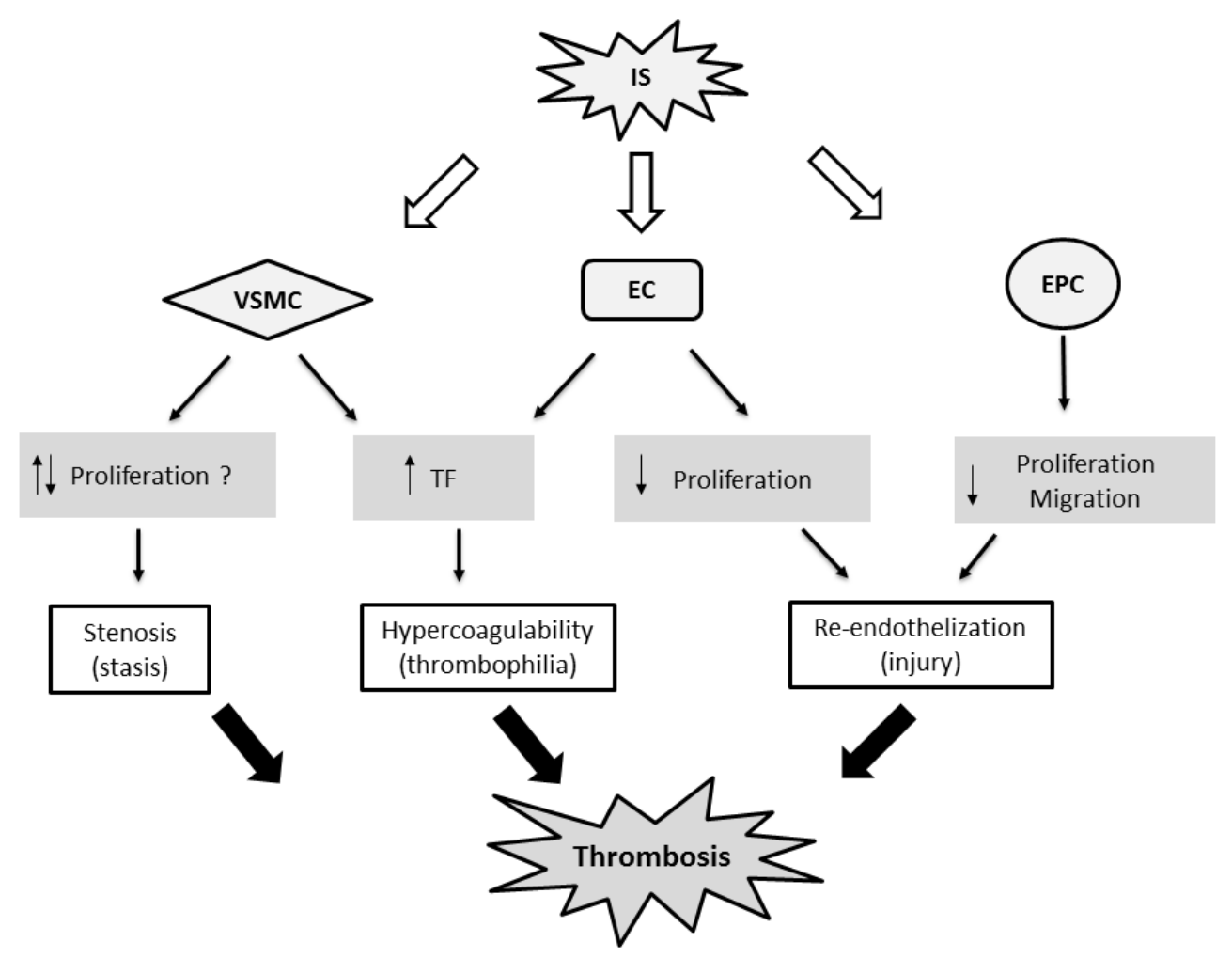

Figure 2. Possible mechanisms of indoxyl sulfate induction of vascular thrombosis. EC, endothelial cell; EPC, endothelial progenitor cell; IS, indoxyl sulfate, TF, tissue factor; VSMC, vascular smooth muscle cell.

\section{Overall Summary}

Traditionally, indoxyl sulfate is considered a vascular toxin involved in atherosclerosis, arteriosclerosis, vascular calcification and vascular repair in patients with CKD. Recent studies have shown that different mechanisms are involved in indoxyl sulfate-related vascular toxicity, including progenitor cell-related neovascularization in PAD and tissue factor-related hypercoagulability in AVGs. Further studies are warranted to validate these novel mechanisms and to explore their clinical applications in patients with CKD.

Acknowledgments: This work was supported by grants from the Novel Bioengineering and Technological Approaches to Solve Two Major Health Problems in Taiwan sponsored by the Taiwan Ministry of Science and Technology Academic Excellence Program (MOST 105-2633-B-009-003) and Research Project (MOST 102-2314-B-010-004-MY3; MOST 105-2314-B-010-016; MOST 104-2314-B-002-206; MOST 105-2314-B-002-119; MOST 103-2314-B-005-MY2; and MOST 105-2314-B-014-MY3), the Ministry of Science and Technology, Republic of China.; Research Project (HCH 104-10, 104-57, 104-58, 105-7, 105-14, 105-24), National Taiwan University Hospital, Hsinchu Branch; and Foundation for Poison Control. These funding agencies had no role in study design, data collection, analysis, decision to publish, or preparation of the manuscript. 
Conflicts of Interest: The authors declare no conflict of interest.

\section{References}

1. Ocak, G.; Vossen, C.Y.; Rotmans, J.I.; Lijfering, W.M.; Rosendaal, F.R.; Parlevliet, K.J.; Krediet, R.T.; Boeschoten, E.W.; Dekker, F.W.; Verduijn, M. Venous and arterial thrombosis in dialysis patients. Thromb. Haemost. 2011, 106, 1046-1052. [CrossRef] [PubMed]

2. Casserly, L.F.; Dember, L.M. Thrombosis in end-stage renal disease. Semin. Dial. 2003, 16, 245-256. [CrossRef] [PubMed]

3. Ocak, G.; van Stralen, K.J.; Rosendaal, F.R.; Verduijn, M.; Ravani, P.; Palsson, R.; Leivestad, T.; Hoitsma, A.J.; Ferrer-Alamar, M.; Finne, P.; et al. Mortality due to pulmonary embolism, myocardial infarction, and stroke among incident dialysis patients. J. Thromb. Haemost. 2012, 10, 2484-2493. [CrossRef] [PubMed]

4. Findlay, M.D.; Thomson, P.C.; Fulton, R.L.; Solbu, M.D.; Jardine, A.G.; Patel, R.K.; Stevens, K.K.; Geddes, C.C.; Dawson, J.; Mark, P.B. Risk factors of ischemic stroke and subsequent outcome in patients receiving hemodialysis. Stroke 2015, 46, 2477-2481. [CrossRef] [PubMed]

5. Trespalacios, F.C.; Taylor, A.J.; Agodoa, L.Y.; Abbott, K.C. Incident acute coronary syndromes in chronic dialysis patients in the united states1. Kidney Int. 2002, 62, 1799-1805. [CrossRef] [PubMed]

6. Rajagopalan, S.; Dellegrottaglie, S.; Furniss, A.L.; Gillespie, B.W.; Satayathum, S.; Lameire, N.; Saito, A.; Akiba, T.; Jadoul, M.; Ginsberg, N.; et al. Peripheral arterial disease in patients with end-stage renal disease: Observations from the Dialysis Outcomes and Practice Patterns Study (DOPPS). Circulation 2006, 114, 1914-1922. [CrossRef] [PubMed]

7. Garimella, P.S.; Hart, P.D.; O'Hare, A.; DeLoach, S.; Herzog, C.A.; Hirsch, A.T. Peripheral artery disease and CKD: A focus on peripheral artery disease as a critical component of CKD care. Am. J. Kidney Dis. 2012, 60, 641-654. [CrossRef] [PubMed]

8. Bethesda, M. US Renal Data System, Usrds 2010 Annual Data Report: Atlas of Chronic Kidney Disease and End-Stage Rena Disease in the United States; National Institutes of Health, National Institute of Diabetes and Digestive and Kidney Diseases: Bethesda, MD, USA, 2010.

9. Neuen, B.L.; Gunnarsson, R.; Webster, A.C.; Baer, R.A.; Golledge, J.; Mantha, M.L. Predictors of patency after balloon angioplasty in hemodialysis fistulas: A systematic review. J. Vasc. Interv. Radiol. 2014, 25, 917-924. [CrossRef] [PubMed]

10. Guerrero, A.; Montes, R.; Muñoz-Terol, J.; Gil-Peralta, A.; Toro, J.; Naranjo, M.; González-Pérez, P.; Martín-Herrera, C.; Ruiz-Fernández, A. Peripheral arterial disease in patients with stages IV and V chronic renal failure. Nephrol. Dial. Transplant. 2006, 21, 3525-3531. [CrossRef] [PubMed]

11. Schwab, S.; Besarab, A.; Beathard, G.; Brouwer, D.; Etheredge, E.; Hartigan, M.; Levine, M.; McCann, R.; Sherman, R.; Trerotola, S. National kidney foundation-dialysis outcomes quality initiative. NKF-DOQI clinical practice guidelines for vascular access. Am. J. Kidney Dis. 1997, 30, S150-S191.

12. Neuen, B.L.; Gunnarsson, R.; Baer, R.A.; Tosenovsky, P.; Green, S.J.; Golledge, J.; Mantha, M.L. Factors associated with patency following angioplasty of hemodialysis fistulae. J. Vasc. Interv. Radiol. 2014, 25, 1419-1426. [CrossRef] [PubMed]

13. Lilly, R.Z.; Carlton, D.; Barker, J.; Saddekni, S.; Hamrick, K.; Oser, R.; Westfall, A.O.; Allon, M. Predictors of arteriovenous graft patency after radiologic intervention in hemodialysis patients. Am. J. Kidney Dis. 2001, 37, 945-953. [CrossRef]

14. Barreto, F.C.; Barreto, D.V.; Liabeuf, S.; Meert, N.; Glorieux, G.; Temmar, M.; Choukroun, G.; Vanholder, R.; Massy, Z.A. Serum indoxyl sulfate is associated with vascular disease and mortality in chronic kidney disease patients. Clin. J. Am. Soc. Nephrol. 2009, 4, 1551-1558. [CrossRef] [PubMed]

15. Lin, C.-J.; Wu, V.; Wu, P.-C.; Wu, C.-J. Meta-analysis of the associations of p-cresyl sulfate (PCS) and indoxyl sulfate (IS) with cardiovascular events and all-cause mortality in patients with chronic renal failure. PLoS ONE 2015, 10, e0132589. [CrossRef] [PubMed]

16. Taki, K.; Tsuruta, Y.; Niwa, T. Indoxyl sulfate and atherosclerotic risk factors in hemodialysis patients. Am. J. Nephrol. 2007, 27, 30-35. [CrossRef] [PubMed]

17. Yu, M.; Kim, Y.J.; Kang, D.-H. Indoxyl sulfate-induced endothelial dysfunction in patients with chronic kidney disease via an induction of oxidative stress. Clin. J. Am. Soc. Nephrol. 2011, 6, 30-39. [CrossRef] [PubMed] 
18. Lin, C.J.; Pan, C.F.; Liu, H.L.; Chuang, C.K.; Jayakumar, T.; Wang, T.J.; Chen, H.H.; Wu, C.J. The role of protein-bound uremic toxins on peripheral artery disease and vascular access failure in patients on hemodialysis. Atherosclerosis 2012, 225, 173-179. [CrossRef] [PubMed]

19. Jourde-Chiche, N.; Dou, L.; Sabatier, F.; Calaf, R.; Cerini, C.; Robert, S.; Camoin-Jau, L.; Charpiot, P.; Argiles, A.; Dignat-George, F.; et al. Levels of circulating endothelial progenitor cells are related to uremic toxins and vascular injury in hemodialysis patients. J. Thromb. Haemost. 2009, 7, 1576-1584. [CrossRef] [PubMed]

20. Tumur, Z.; Shimizu, H.; Enomoto, A.; Miyazaki, H.; Niwa, T. Indoxyl sulfate upregulates expression of ICAM-1 and MCP-1 by oxidative stress-induced NF-kappa $\beta$ activation. Am. J. Nephrol. 2010, 31, 435-441. [CrossRef] [PubMed]

21. Muteliefu, G.; Enomoto, A.; Jiang, P.; Takahashi, M.; Niwa, T. Indoxyl sulphate induces oxidative stress and the expression of osteoblast-specific proteins in vascular smooth muscle cells. Nephrol. Dial. Transplant. 2009, 24, 2051-2058. [CrossRef] [PubMed]

22. Adijiang, A.; Goto, S.; Uramoto, S.; Nishijima, F.; Niwa, T. Indoxyl sulphate promotes aortic calcification with expression of osteoblast-specific proteins in hypertensive rats. Nephrol. Dial. Transplant. 2008, 23, 1892-1901. [CrossRef] [PubMed]

23. Muteliefu, G.; Enomoto, A.; Niwa, T. Indoxyl sulfate promotes proliferation of human aortic smooth muscle cells by inducing oxidative stress. J. Ren. Nutr. 2009, 19, 29-32. [CrossRef] [PubMed]

24. Yamamoto, H.; Tsuruoka, S.; Ioka, T.; Ando, H.; Ito, C.; Akimoto, T.; Fujimura, A.; Asano, Y.; Kusano, E. Indoxyl sulfate stimulates proliferation of rat vascular smooth muscle cells. Kidney Int. 2006, 69, 1780-1785. [CrossRef] [PubMed]

25. Dou, L.; Bertrand, E.; Cerini, C.; Faure, V.; Sampol, J.; Vanholder, R.; Berland, Y.; Brunet, P. The uremic solutes p-cresol and indoxyl sulfate inhibit endothelial proliferation and wound repair. Kidney Int. 2004, 65, 442-451. [CrossRef] [PubMed]

26. Dou, L.; Jourde-Chiche, N.; Faure, V.; Cerini, C.; Berland, Y.; Dignat-George, F.; Brunet, P. The uremic solute indoxyl sulfate induces oxidative stress in endothelial cells. J. Thromb. Haemost. 2007, 5, 1302-1308. [CrossRef] [PubMed]

27. Itoh, Y.; Ezawa, A.; Kikuchi, K.; Tsuruta, Y.; Niwa, T. Protein-bound uremic toxins in hemodialysis patients measured by liquid chromatography/tandem mass spectrometry and their effects on endothelial ROS production. Anal. Bioanal. Chem. 2012, 403, 1841-1850. [CrossRef] [PubMed]

28. Faure, V.; Dou, L.; Sabatier, F.; Cerini, C.; Sampol, J.; Berland, Y.; Brunet, P.; Dignat-George, F. Elevation of circulating endothelial microparticles in patients with chronic renal failure. J. Thromb. Haemost. 2006, 4, 566-573. [CrossRef] [PubMed]

29. Gondouin, B.; Cerini, C.; Dou, L.; Sallee, M.; Duval-Sabatier, A.; Pletinck, A.; Calaf, R.; Lacroix, R.; Jourde-Chiche, N.; Poitevin, S.; et al. Indolic uremic solutes increase tissue factor production in endothelial cells by the aryl hydrocarbon receptor pathway. Kidney Int. 2013, 84, 733-744. [CrossRef] [PubMed]

30. Kharait, S.; Haddad, D.J.; Springer, M.L. Nitric oxide counters the inhibitory effects of uremic toxin indoxyl sulfate on endothelial cells by governing ERK MAP kinase and myosin light chain activation. Biochem. Biophys. Res. Commun. 2011, 409, 758-763. [CrossRef] [PubMed]

31. Mozar, A.; Louvet, L.; Morliere, P.; Godin, C.; Boudot, C.; Kamel, S.; Drueke, T.B.; Massy, Z.A. Uremic toxin indoxyl sulfate inhibits human vascular smooth muscle cell proliferation. Ther. Apher. Dial. 2011, 15, 135-139. [CrossRef] [PubMed]

32. Chitalia, V.C.; Shivanna, S.; Martorell, J.; Balcells, M.; Bosch, I.; Kolandaivelu, K.; Edelman, E.R. Uremic serum and solutes increase post-vascular interventional thrombotic risk through altered stability of smooth muscle cell tissue factor. Circulation 2013, 127, 365-376. [CrossRef] [PubMed]

33. Ito, S.; Osaka, M.; Higuchi, Y.; Nishijima, F.; Ishii, H.; Yoshida, M. Indoxyl sulfate induces leukocyte-endothelial interactions through up-regulation of E-selectin. J. Biol. Chem. 2010, 285, 38869-38875. [CrossRef] [PubMed]

34. Pletinck, A.; Glorieux, G.; Schepers, E.; Cohen, G.; Gondouin, B.; Van Landschoot, M.; Eloot, S.; Rops, A.; Van de Voorde, J.; De Vriese, A.; et al. Protein-bound uremic toxins stimulate crosstalk between leukocytes and vessel wall. J. Am. Soc. Nephrol. 2013, 24, 1981-1994. [CrossRef] [PubMed]

35. Lekawanvijit, S.; Adrahtas, A.; Kelly, D.J.; Kompa, A.R.; Wang, B.H.; Krum, H. Does indoxyl sulfate, a uraemic toxin, have direct effects on cardiac fibroblasts and myocytes? Eur. Heart J. 2010, 31, 1771-1779. [CrossRef] [PubMed] 
36. Wu, V.C.; Young, G.H.; Huang, P.H.; Lo, S.C.; Wang, K.C.; Sun, C.Y.; Liang, C.J.; Huang, T.M.; Chen, J.H.; Chang, F.C.; et al. In acute kidney injury, indoxyl sulfate impairs human endothelial progenitor cells: Modulation by statin. Angiogenesis 2013, 16, 609-624. [CrossRef] [PubMed]

37. Hung, S.C.; Kuo, K.L.; Huang, H.L.; Lin, C.C.; Tsai, T.H.; Wang, C.H.; Chen, J.W.; Lin, S.J.; Huang, P.H.; Tarng, D.C. Indoxyl sulfate suppresses endothelial progenitor cell-mediated neovascularization. Kidney Int. 2016, 89, 574-585. [CrossRef] [PubMed]

38. Tumur, Z.; Niwa, T. Indoxyl sulfate inhibits nitric oxide production and cell viability by inducing oxidative stress in vascular endothelial cells. Am. J. Nephrol. 2009, 29, 551-557. [CrossRef] [PubMed]

39. Eggers, P.W.; Gohdes, D.; Pugh, J. Nontraumatic lower extremity amputations in the medicare end-stage renal disease population. Kidney Int. 1999, 56, 1524-1533. [CrossRef] [PubMed]

40. Jacobi, J.; Porst, M.; Cordasic, N.; Namer, B.; Schmieder, R.E.; Eckardt, K.U.; Hilgers, K.F. Subtotal nephrectomy impairs ischemia-induced angiogenesis and hindlimb re-perfusion in rats. Kidney Int. 2006, 69, 2013-2021. [CrossRef] [PubMed]

41. Yancopoulos, G.D.; Davis, S.; Gale, N.W.; Rudge, J.S.; Wiegand, S.J.; Holash, J. Vascular-specific growth factors and blood vessel formation. Nature 2000, 407, 242-248. [CrossRef] [PubMed]

42. Murasawa, S.; Asahara, T. Endothelial progenitor cells for vasculogenesis. Physiology (Bethesda) 2005, 20, 36-42. [CrossRef] [PubMed]

43. De Groot, K.; Bahlmann, F.H.; Sowa, J.; Koenig, J.; Menne, J.; Haller, H.; Fliser, D. Uremia causes endothelial progenitor cell deficiency. Kidney Int. 2004, 66, 641-646. [CrossRef] [PubMed]

44. Shivanna, S.; Kolandaivelu, K.; Shashar, M.; Belghasim, M.; Al-Rabadi, L.; Balcells, M.; Zhang, A.; Weinberg, J.; Francis, J.; Pollastri, M.P.; et al. The aryl hydrocarbon receptor is a critical regulator of tissue factor stability and an antithrombotic target in uremia. J. Am. Soc. Nephrol. 2016, 27, 189-201. [CrossRef] [PubMed]

45. Sallee, M.; Dou, L.; Cerini, C.; Poitevin, S.; Brunet, P.; Burtey, S. The aryl hydrocarbon receptor-activating effect of uremic toxins from tryptophan metabolism: A new concept to understand cardiovascular complications of chronic kidney disease. Toxins (Basel) 2014, 6, 934-949. [CrossRef] [PubMed]

46. Schwab, S.J.; Harrington, J.T.; Singh, A.; Roher, R.; Shohaib, S.A.; Perrone, R.D.; Meyer, K.; Beasley, D. Vascular access for hemodialysis. Kidney Int. 1999, 55, 2078-2090. [CrossRef] [PubMed]

47. Crowther, M.A.; Kelton, J.G. Congenital thrombophilic states associated with venous thrombosis: A qualitative overview and proposed classification system. Ann. Intern. Med. 2003, 138, 128-134. [CrossRef] [PubMed]

48. Chang, T.I.; Paik, J.; Greene, T.; Desai, M.; Bech, F.; Cheung, A.K.; Chertow, G.M. Intradialytic hypotension and vascular access thrombosis. J. Am. Soc. Nephrol. 2011, 22, 1526-1533. [CrossRef] [PubMed]

49. Sarkar, O.; Assadian, A.; Frank, H.; Moessmer, G.; Heemann, U.; Eckstein, H.H. Hereditary and acquired thrombophilic disorders complicating vascular access in haemodialysisl. NDT Plus 2010, 3, 393-396. [PubMed]

50. Baskin, E.; Duman, O.; Besbas, N.; Ozen, S. Hypercoagulopathy in a hemodialysis patient: Are elevations in factors VII and VIII effective? Nephron 1999, 83, 180. [CrossRef] [PubMed]

51. Segarra, A.; Chacon, P.; Martinez-Eyarre, C.; Argelaguer, X.; Vila, J.; Ruiz, P.; Fort, J.; Bartolome, J.; Camps, J.; Moliner, E.; et al. Circulating levels of plasminogen activator inhibitor type-1, tissue plasminogen activator, and thrombomodulin in hemodialysis patients: Biochemical correlations and role as independent predictors of coronary artery stenosis. J. Am. Soc. Nephrol. 2001, 12, 1255-1263. [PubMed]

52. Malyszko, J.; Malyszko, J.S.; Hryszko, T.; Mysliwiec, M. Thrombin activatable fibrinolysis inhibitor (TAFI) and markers of endothelial cell injury in dialyzed patients with diabetic nephropathy. Thromb. Haemost. 2004, 91, 480-486. [CrossRef] [PubMed]

53. Mercier, E.; Branger, B.; Vecina, F.; Al-Sabadani, B.; Berlan, J.; Dauzat, M.; Fourcade, J.; Gris, J.C. Tissue factor coagulation pathway and blood cells activation state in renal insufficiency. Hematol. J. 2001, 2, 18-25. [CrossRef] [PubMed]

54. Knoll, G.A.; Wells, P.S.; Young, D.; Perkins, S.L.; Pilkey, R.M.; Clinch, J.J.; Rodger, M.A. Thrombophilia and the risk for hemodialysis vascular access thrombosis. J. Am. Soc. Nephrol. 2005, 16, 1108-1114. [CrossRef] [PubMed]

55. Salmela, B.; Hartman, J.; Peltonen, S.; Albäck, A.; Lassila, R. Thrombophilia and arteriovenous fistula survival in ESRD. Clin. J. Am. Soc. Nephrol. 2013, 8, 962-968. [CrossRef] [PubMed] 
56. Nampoory, M.R.; Das, K.C.; Johny, K.V.; Al-Hilali, N.; Abraham, M.; Easow, S.; Saed, T.; Al-Muzeirei, I.A.; Sugathan, T.N.; Al Mousawi, M. Hypercoagulability, a serious problem in patients with ESRD on maintenance hemodialysis, and its correction after kidney transplantation. Am. J. Kidney Dis. 2003, 42, 797-805. [CrossRef]

57. Wu, C.C.; Hsieh, M.Y.; Hung, S.C.; Kuo, K.L.; Tsai, T.H.; Lai, C.L.; Chen, J.W.; Lin, S.J.; Huang, P.H.; Tarng, D.C. Serum indoxyl sulfate associates with postangioplasty thrombosis of dialysis grafts. J. Am. Soc. Nephrol. 2016, 27, 1254-1264. [CrossRef] [PubMed]

58. Miyazaki, T.; Ise, M.; Hirata, M.; Endo, K.; Ito, Y.; Seo, H.; Niwa, T. Indoxyl sulfate stimulates renal synthesis of transforming growth factor-beta 1 and progression of renal failure. Kidney Int. Suppl. 1997, 63, S211-S214. [PubMed]

59. Yisireyili, M.; Saito, S.; Abudureyimu, S.; Adelibieke, Y.; Ng, H.-Y.; Nishijima, F.; Takeshita, K.; Murohara, T.; Niwa, T. Indoxyl sulfate-induced activation of (pro)renin receptor promotes cell proliferation and tissue factor expression in vascular smooth muscle cells. PLoS ONE 2014, 9, e109268. [CrossRef] [PubMed]

60. Muteliefu, G.; Shimizu, H.; Enomoto, A.; Nishijima, F.; Takahashi, M.; Niwa, T. Indoxyl sulfate promotes vascular smooth muscle cell senescence with upregulation of p53, p21, and prelamin a through oxidative stress. Am. J. Physiol. Cell Physiol. 2012, 303, C126-C134. [CrossRef] [PubMed]

61. Sata, M.; Saiura, A.; Kunisato, A.; Tojo, A.; Okada, S.; Tokuhisa, T.; Hirai, H.; Makuuchi, M.; Hirata, Y.; Nagai, R. Hematopoietic stem cells differentiate into vascular cells that participate in the pathogenesis of atherosclerosis. Nat. Med. 2002, 8, 403-409. [CrossRef] [PubMed]

62. Wu, C.C.; Huang, P.H.; Lai, C.L.; Leu, H.B.; Chen, J.W.; Lin, S.J. The impact of endothelial progenitor cells on restenosis after percutaneous angioplasty of hemodialysis vascular access. PLoS ONE 2014, 9, e101058. [CrossRef] [PubMed]

63. Lev, E.I.; Leshem-Lev, D.; Mager, A.; Vaknin-Assa, H.; Harel, N.; Zimra, Y.; Bental, T.; Greenberg, G.; Dvir, D.; Solodky, A.; et al. Circulating endothelial progenitor cell levels and function in patients who experienced late coronary stent thrombosis. Eur. Heart J. 2010, 31, 2625-2632. [CrossRef] [PubMed]

64. Chen, T.Y.; Lin, T.T.; Hsieh, M.Y.; Lin, L.; Yang, C.W.; Chuang, S.Y.; Huang, P.H.; Wu, C.C. Circulating progenitor cells affect thrombosis of dialysis arteriovenous fistulas. Am. J. Nephrol. 2016, 44, 428-438. [CrossRef] [PubMed]

(C) 2017 by the authors; licensee MDPI, Basel, Switzerland. This article is an open access article distributed under the terms and conditions of the Creative Commons Attribution (CC-BY) license (http:/ / creativecommons.org/licenses/by/4.0/). 